\title{
Implementasi Labview Untuk Pemantauan Pemakaian Energi Listrik
}

\author{
Muhammad Yusuf Yunus \\ Energy Conversion Study Program \\ State Polytechnic of Ujung Pandang \\ Makassar, Indonesia \\ e-mail: yusuf_yunus@poliupg.ac.id
}

\author{
Marhatang \\ Energy Conversion Study Program \\ State Polytechnic of Ujung Pandang \\ Makassar, Indonesia \\ e-mail: marhatang@poliupg.ac.id
}

\begin{abstract}
Abstrak -. Dalam perangkat pengukuran listrik konvensional, pengukuran dilakukan pada penggunaan energi listrik secara keseluruhan dimana konsumen hanya dapat melihat informasi tentang hasil penggunaan energi listrik dengan melihat jumlah total konsumsi daya yang tertera pada meteran meteran $k W h$. Berdasarkan permasalahan di atas, penulis bertujuan untuk menaikkan judul "Desain Sistem Monitoring Penggunaan Energi Listrik dengan Menggunakan LabVIEW". Program LabVIEW memiliki kemampuan untuk mengukur, memantau, dan menyimpan data dengan cepat dan akurat. Dengan alat ini akan terwujud suatu sistem desain pemantauan penggunaan energi listrik secara real time melalui komputer bukan $\mathbf{k W H}$ meter analog atau digital. Konsep ini adalah salah satu solusi manajemen energi yang memungkinkan konsumen untuk memperoleh data statistik mengenai konsumsi energi listrik secara detail. Dari hasil pemantauan penggunaan beban, diperoleh hasil yang sangat baik dalam memonitor penggunaan energi, yang dalam hal ini menggunakan beban rumah tangga.
\end{abstract}

Abstract In conventional electric measurement devices, measurements are made on the use of electrical energy as a whole where consumers can only see information on the results of the use of electrical energy by looking at the total power consumption amount indicated on the meter $\mathrm{kWh}$ meter. Based on the above problems, the author aims to raise the title "Design of Monitoring System of Electricity Energy Usage using LabVIEW". The LabVIEW program has the ability to measure, monitor and store data quickly and accurately. With this tool will be realized a design system monitoring the use of electrical energy in real time through the computer instead of $\mathrm{kWH}$ meter analog or digital. This concept is one of the energy management solutions that enable consumers to obtain statistical data on electrical energy consumption in detail. From the results of monitoring the use of loads, obtained very good results in monitoring the usage of energy, which in this case using household burden.

Keywords: LabView, ACS712, Current, Monitoring

\section{INTRODUCTION}

Energi listrik memiliki peran yang sangat penting dalam kehidupan masyarakat karena energi listrik merupakan parameter penting bagi pembangunan dan pertumbuhan ekonomi. Seiring dengan pertumbuhan ekonomi dan tingkat populasi penduduk di Indonesia yang semakin tinggi maka permintaan akan energi listrik juga meningkat. Namun, ketersediaan sumber energi listrik tidak mampu memenuhi peningkatan kebutuhan listrik tersebut. Terjadinya pemadaman listrik dan pembagian energi listrik secara bergilir merupakan dampak dari terbatasnya energi listrik yang dapat di supply oleh PLN. Hal ini terjadi karena laju pertambahan sumber energi baru dan pengadaan pembangkit tenaga listrik tidak sebanding dengan peningkatan konsumsi energi listrik [1].

Kebutuhan energi listrik yang melunjak diakibatkan oleh para konsumen yang tidak efektif dalam penggunaan atau terjadi pemborosan. Menurut [2] "Konsumen disini terdiri dari beberapa sektor dengan didominasi pada sektor rumah tangga dengan pangsa lebih dari $41 \%$. Selain itu sektor industri dengan pangsa $34 \%$ dan sektor komersil 24\%". Pada sektor rumah tangga, energi listrik berfungsi untuk penerangan, memasak, pemanas, dan pendingin. Dalam pemanfaatan energi listrik ini terkadang tidak diketahui berapa banyak energi yang telah terpakai sehingga cenderung terjadi pemborosan. Oleh karena itu, untuk mengetahui besarnya energi listrik yang sedang terpakai, perlu dilakukan pengukuran penggunaan energi listrik secara terus-menerus (real time).

Pada alat pengukuran listrik konvensional, pengukuran dilakukan terhadap penggunaaan energi listrik secara keseluruhan dimana konsumen hanya dapat melihat informasi hasil dari penggunaan energi listrik dengan melihat jumlah pemakaian daya total yang tertera pada alat ukur $\mathrm{kWh}$ meter. Dengan pemantauan secara terperinci, konsumen dapat membuat pola penghematan penggunaan energi listrik dan dengan demikian konsumen bisa memantau penggunaan listrik dan mengurangi pemborosan serta dapat menekan biaya yang dikeluarkan akibat penggunaan energi listrik tersebut.

Sistem pemantauan energi listrik adalah sistem yang digunakan untuk mengukur penggunaan energi listrik yang dipakai oleh beban. Pemantauan terhadap pemakaian energi listrik diperlukan untuk mengurangi penggunaan daya energi 


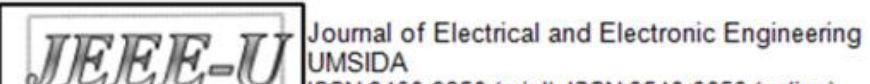 \\ ISSN $2460-9250$ (print), ISSN 2540-8658 (online) \\ Vol. 2, No. 1, April 2018}

listrik berlebihan, untuk itu perlu adanya instrumen pengukur yang dapat memantau penggunaan daya listrik dan batasan penggunaan daya.

Saat ini, berbagai peralatan pemantauan dan pengukuran energi listrik juga semakin canggih mulai dari pemakaian meter transaksi oleh PT. PLN pada setiap distribusi dan transmisi, Power Quality Analyzer (PQA) yang umum dipakai para laboran atau auditor energi, dan $\mathrm{kWh}$ meter elektronik yang dipakai masyarakat di setiap rumah [3]. Dalam literatur beberapa kasus monitoring energi listrik, telah banyak metode inovatif yang digunakan seperti dalam Rancang Bangun Alat Pemantau Penggunaan Energi Listrik Rumah Tangga Berbasis Internet [2], dimana alat ini menggunakan system pemantau dan penghitung jarak jauh penggunaan daya listrik pada suatu alat elektronik maupun keseluruhan penggunaan daya listrik pada rumah tangga dengan menggunakan transmisi data media internet, dimana daya listrik yang terpakai bisa ditampilkan pada halaman web.

Berdasarkan permasalahan diatas, penulis bertujuan mengangkat judul "Rancang Bangun Sistem Pemantauan Pemakaian Energi Listrik menggunakan LabVIEW". Program LabVIEW mempunyai kemampuan mengukur, memonitor dan menyimpan data dengan cepat dan akurat [4]. Dengan alat ini akan direalisasikan suatu desain sistem monitoring pemakaian energi listrik secara real time melalui komputer sebagai pengganti $\mathrm{kWH}$ meter analog maupun digital. Konsep ini merupakan salah satu solusi manajemen energi yang memungkinkan konsumen untuk memperoleh data statistik konsumsi energi listrik secara terperinci. Pengembangan lebih lanjut tentang penelitian ini adalah berbasis kecerdasan buatan seperti $[1,5,6]$.

\section{Metode Penelitian}

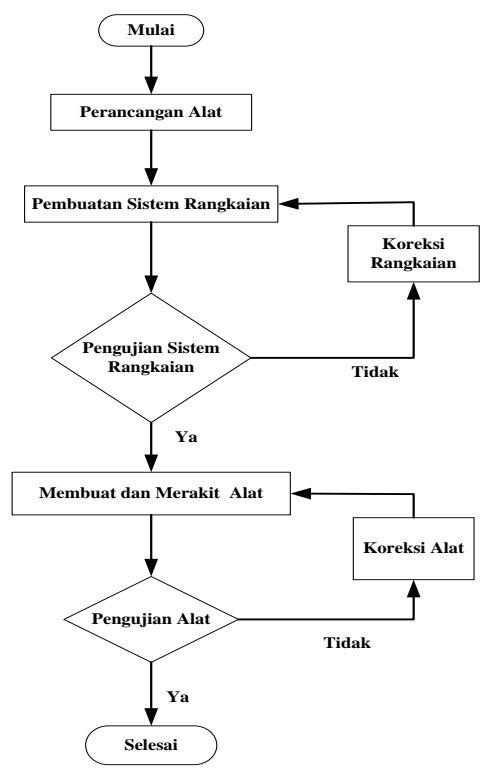

Gambar 1. Flowchart Langkah Kerja

Pada bagian ini prosedur atau langkah kerja terdiri atas :

\subsection{Tahap Perancangan}

Tahap perancangan merupakan proses mendesain rangkaian dengan kata lain menganalisis dan membuat pola rancangan rangkaian yang merupakan langkah awal sebelum digunakan untuk menunjang kinerja sistem.

Adapun desain dari alat pemantauan energi listrik menggunakan LabVIEW yang akan dibuat dapat dilihat pada Gambar berikut.

Perancangan sistem yang akan dibangun dibagi menjadi 2 bagian, yaitu perancangan perangkat keras (Hardware) dan perancangan perangkat lunak (Software).

\subsubsection{Perancangan Perangkat Keras ( Hardware)}

Rancangan sistem perangkat keras merupakan rangkaian dari beberapa komponen, yaitu sumber listrik satu fasa (1Ø), transformator CT, catu daya $5 \mathrm{~V}$, sensor arus ACS712, arduino uno, sebuah laptop dan beberapa peralatan listrik rumah tangga sebagai beban. Sumber satu fasa sebagai perangkat atau sistem yang memasok energi listrik ke peralatan listrik. Sensor arus akan mendeteksi arus listrik yang masuk ke beban peralatan listrik, kemudian hasil pembacaan sensor arus tersebut akan diteruskan ke mikrokontoler arduino mega 2560 untuk proses akuisisi data. Hasil olahan dari arduino akan ditampilkan pada laptop/komputer.

\subsubsection{Perancangan Perangkat Lunak (software)}

Pembuatan perangkat keras modul pendeteksi dilanjutkan dengan pembuatan software aplikasi menggunakan bahasa pemrograman grafis National Instrument LabVIEW. Sistem monitoring yang dibuat menggunakan software LabVIEW, dimana program dibuat dalam bentuk diagram rangkaian (dalam menu block diagram) dan data ditampilkan dalam menu front panel. Untuk menampilkan dan mengakuisisi semua data maka akan dibuat diagram rangkaian.

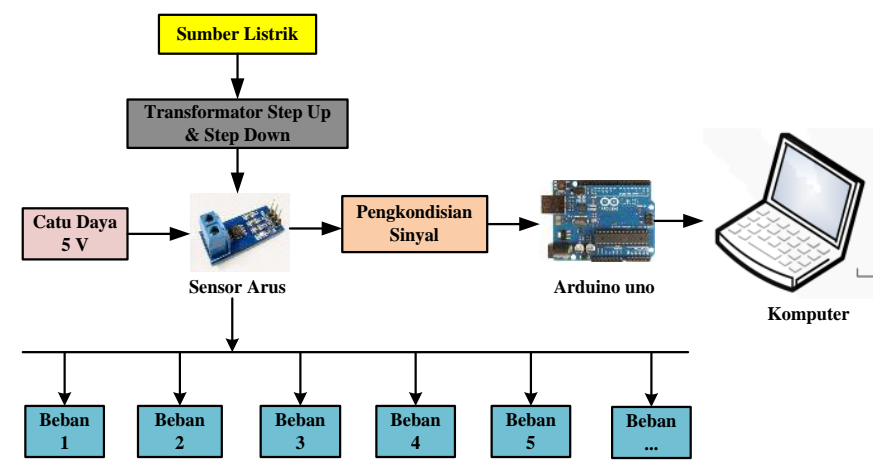

Gambar 2 Perancangan Sistem Pemantauan Pemakaian Energi Listrik 


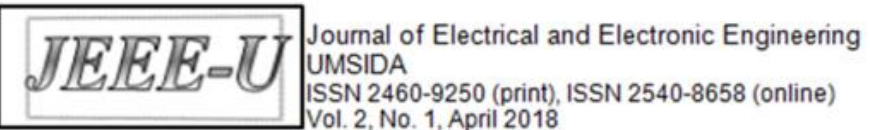

Vol. 2, No. 1, April 2018

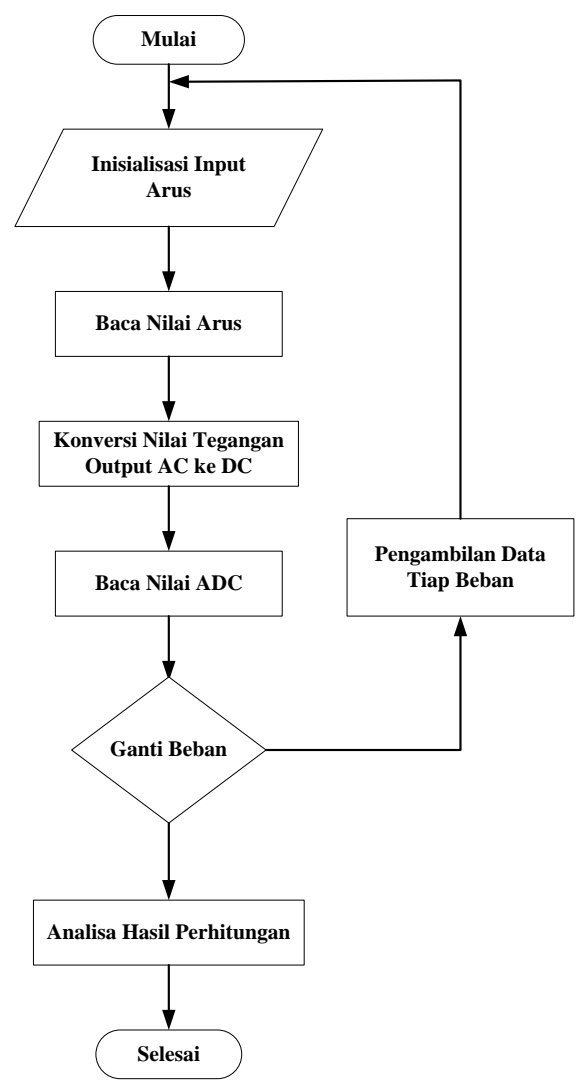

Gambar 3. Flowchart Pengujian Sistem Pemantauan Energi Listrik

\section{RESUltS AND DiscuSSION}

\subsection{Pengujian Beban Tunggal}

\subsubsection{Beban Dispenser 350 W}

Pada gambar 4.12 merupakan bentuk karekteristik gelombang arus pada pengujian beban dispenser. Pada pengujian arus menggunakan multimeter menunjukan nilai sebesar 1,7 A, sedangkan pada pengujian dengan menggunakan LabVIEW menunjukan nilai arus sebesar 1,64 A. Dari hasil tersebut dapat diketahui bahwa terdapat perbedaan nilai arus pada kedua pengujian dengan selisih (error) nilai arus sebesar 0,06 A.

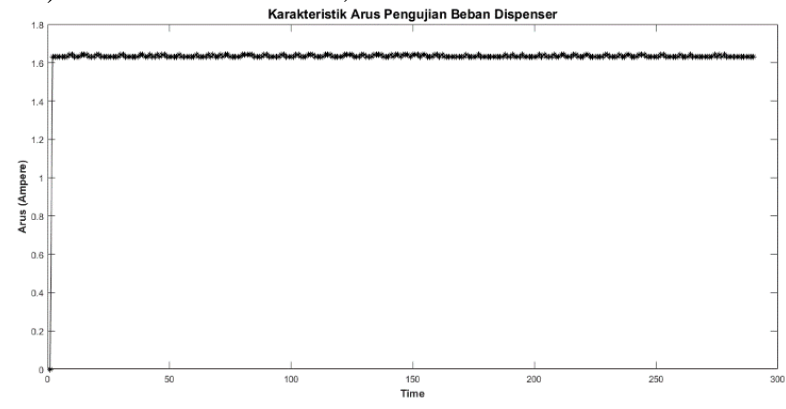

Gambar 4 Karakteristik Pengujian Beban Dispenser

\subsubsection{Beban Heater 1000 W}

Pada gambar 4.14 merupakan bentuk karekteristik gelombang arus pada pengujian beban heater. Pada pengujian arus menggunakan multimeter menunjukan nilai sebesar 3,09 A, sedangkan pada pengujian dengan menggunakan LabVIEW menunjukan nilai arus sebesar 2,95 A. Dari hasil tersebut dapat diketahui bahwa terdapat perbedaan nilai arus pada kedua pengujian dengan selisih (error) nilai arus sebesar 0,14 A.

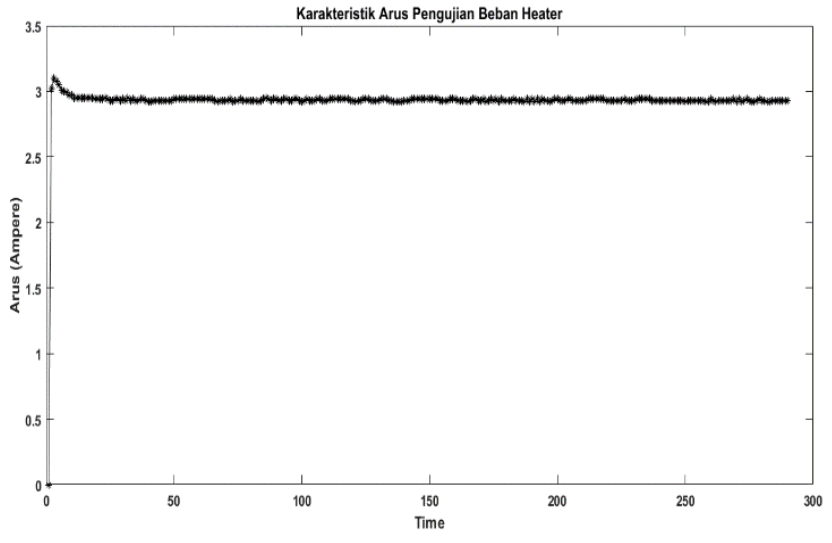

Gambar 5 Karakteristik Pengujian Beban Heater

\subsubsection{Beban Setrika 350 W}

Pada gambar 4.16 merupakan bentuk karekteristik gelombang arus pada pengujian beban setrika. Dari grafik tersebut terlihat bahwa bentuk gelombang arus fluktuatif hal ini disebabkan karena pada beban setrika terdapat elemen thermostat yang ketika temperatur telah mencapai klimaks (sesuai dengan pengaturan pada selector switch) otomatis akan memutuskan hubung pada elemen pemanas sehingga setrika pada kondisi "OFF" (arus nol) dan akan kembali "ON" ketika suhu termostat menurun. Pada pengujian arus menggunakan multimeter menunjukan nilai sebesar 1,75 A, sedangkan pada pengujian dengan menggunakan LabVIEW menunjukan nilai arus sebesar 1,69 A. Dari hasil tersebut dapat diketahui bahwa terdapat perbedaan nilai arus pada kedua pengujian dengan selisih (error) nilai arus sebesar 0,06 A.

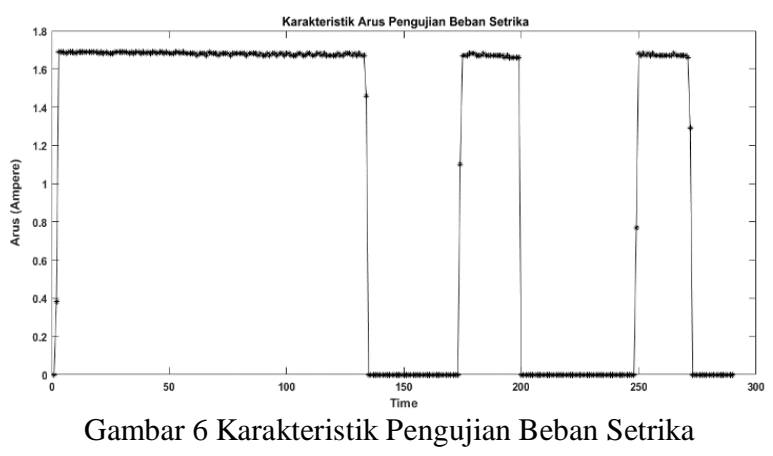




\subsubsection{Beban Lampu 45 W}

Pada gambar 4.18 merupakan bentuk karekteristik gelombang arus pada pengujian beban lampu. Pada pengujian arus menggunakan multimeter menunjukan nilai sebesar $0,18 \mathrm{~A}$, sedangkan pada pengujian dengan menggunakan LabVIEW menunjukan nilai arus sebesar 0,23 A. Dari hasil tersebut dapat diketahui bahwa terdapat perbedaan nilai arus pada kedua pengujian dengan selisih (error) nilai arus sebesar 0,05 A.

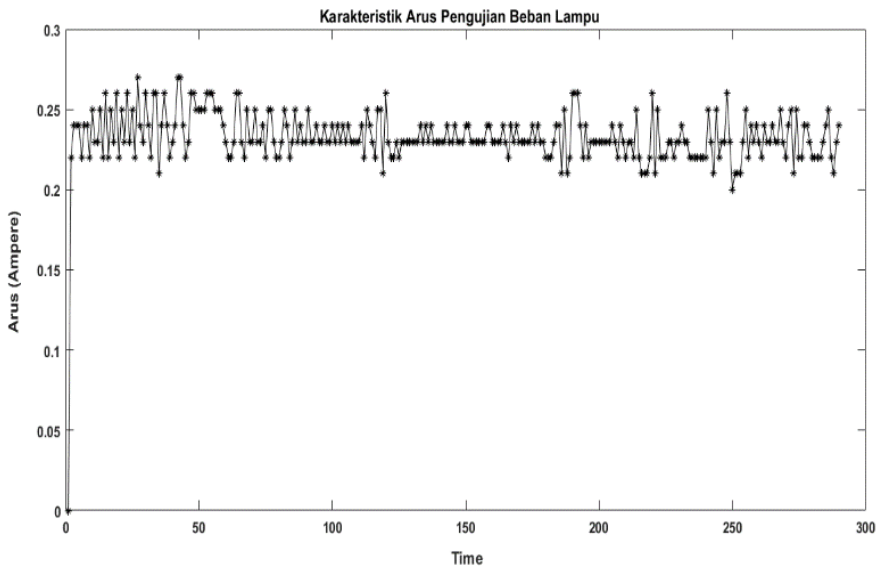

Gambar 7 Karakteristik Pengujian Beban Lampu

\subsection{Pengujian Kombinasi Beban}

\subsubsection{Dispenser 350 W + Heater $1000 \mathrm{~W}$}

Pada gambar 4.20 merupakan bentuk karekteristik gelombang arus pada pengujian beban kombinasi dispenser dan heater. Pada pengujian arus menggunakan multimeter menunjukan nilai sebesar 4,86 A, sedangkan pada pengujian dengan menggunakan LabVIEW menunjukan nilai arus sebesar 4,6 A. Dari hasil tersebut dapat diketahui bahwa terdapat perbedaan nilai arus pada kedua pengujian dengan selisih (error) nilai arus sebesar $0,26 \mathrm{~A}$.

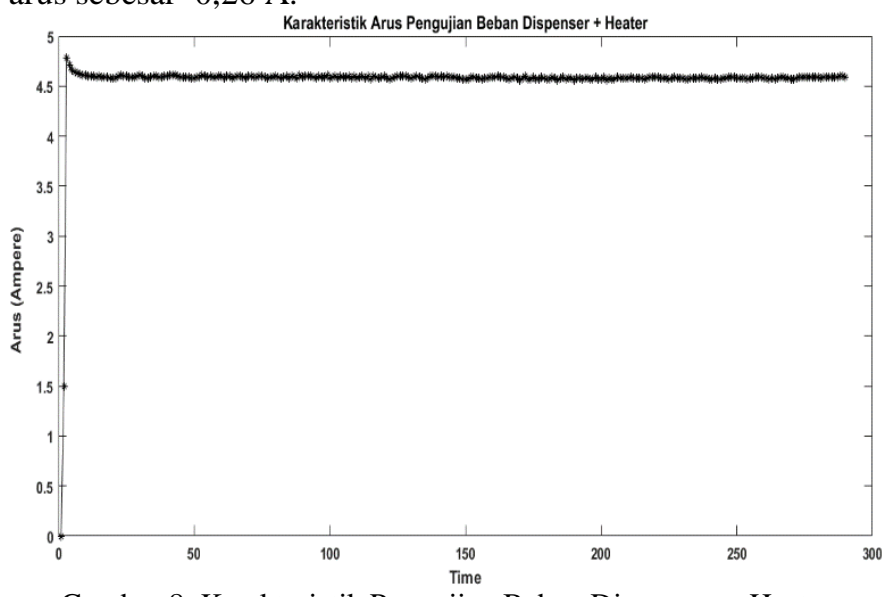

Gambar 8 Karakteristik Pengujian Beban Dispenser + Heater

\subsubsection{Beban Heater 1000 W dan Lampu $45 \mathrm{~W}$}

Pada gambar 4.22 merupakan bentuk karekteristik gelombang arus pada pengujian beban kombinasi heater dan lampu. Pada pengujian arus menggunakan multimeter menunjukan nilai sebesar 3,26 A, sedangkan pada pengujian dengan menggunakan LabVIEW menunjukan nilai arus sebesar 3,11 A. Dari hasil tersebut dapat diketahui bahwa terdapat perbedaan nilai arus pada kedua pengujian dengan selisih (error) nilai arus sebesar $0,15 \mathrm{~A}$.

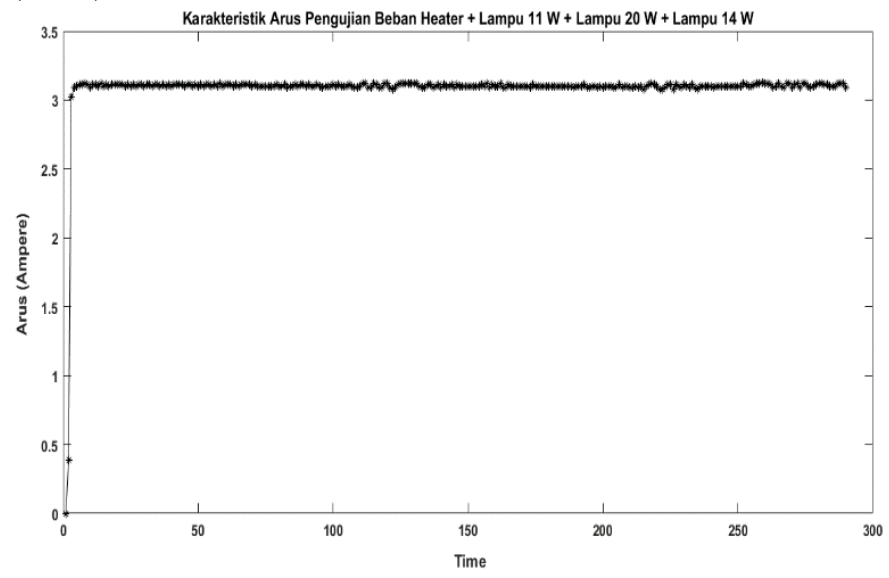

Gambar 9 Karakteristik Pengujian Beban Heater 1000 W dan Lampu $45 \mathrm{~W}$

\subsubsection{Beban Setrika 350 W dan Lampu $45 \mathrm{~W}$}

Pada gambar 4.24 merupakan bentuk karekteristik gelombang arus pada pengujian beban setrika dan lampu. Dari grafik tersebut terlihat bahwa bentuk gelombang arus berfluktuatif hal ini disebabkan karena terdapat beban setrika yang akan otomatis OFF apabila mencapai titik panas maksimun. Pada pengujian arus menggunakan multimeter menunjukan nilai sebesar 1,9 A, sedangkan pada pengujian dengan menggunakan LabVIEW menunjukan nilai arus sebesar 1,83 A. Dari hasil tersebut dapat diketahui bahwa terdapat perbedaan nilai arus pada kedua pengujian dengan selisih (error) nilai arus sebesar 0,07 A.

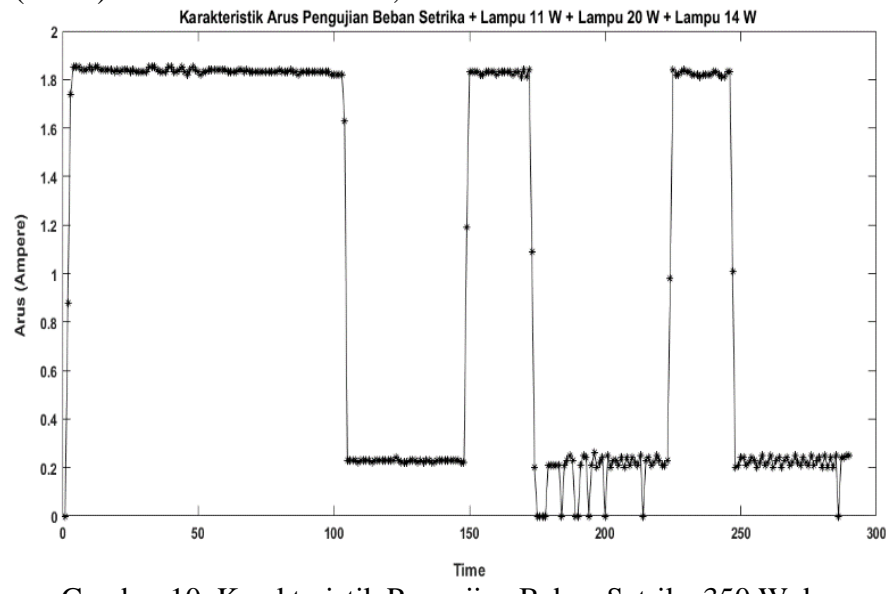

Gambar 10 Karakteristik Pengujian Beban Setrika 350 W dan Lampu $45 \mathrm{~W}$ 


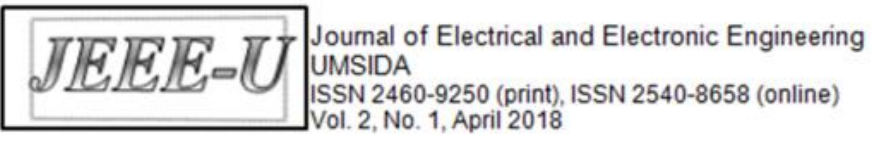

\subsubsection{Beban Dispenser 350 W, Setrika 350 W dan Lampu $20 \mathrm{~W}$}

Pada gambar 4.26 merupakan bentuk karekteristik gelombang arus pada pengujian beban setrika dan lampu. Dari grafik tersebut terlihat bahwa bentuk gelombang arus berfluktuatif hal ini disebabkan karena terdapat beban setrika yang akan otomatis "OFF" apabila mencapai titik panas maksimun. Pada pengujian arus menggunakan multimeter menunjukan nilai sebesar 3,52 A, sedangkan pada pengujian dengan menggunakan LabVIEW menunjukan nilai arus sebesar 3,38 A. Dari hasil tersebut dapat diketahui bahwa terdapat perbedaan nilai arus pada kedua pengujian dengan selisih (error) nilai arus sebesar $0,14 \mathrm{~A}$.

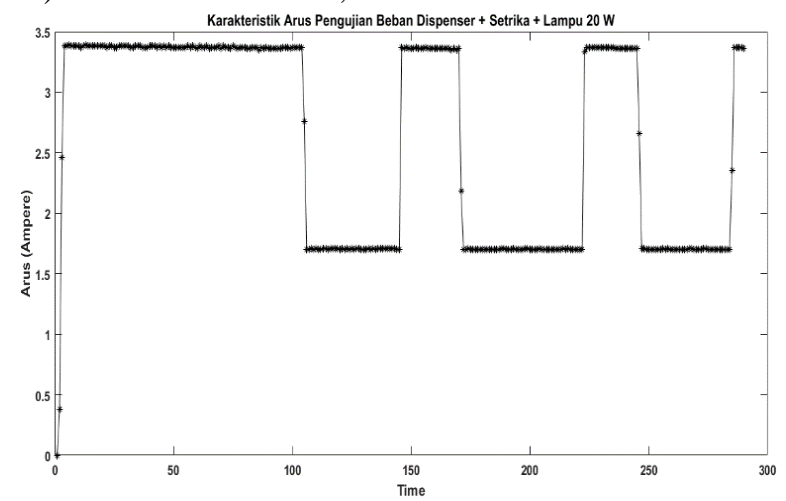

Gambar 11 Karakteristik Pengujian Beban Dispenser 350 W, Setrika $350 \mathrm{~W}$, dan Lampu $20 \mathrm{~W}$

\subsubsection{Beban Dispenser 350 W, Heater 1000 W, Setrika 350 W, Lampu 45 W}

Pada gambar 4.28 merupakan bentuk karekteristik gelombang arus pada pengujian beban dispenser, heater, setrika, dan lampu. Dari grafik tersebut terlihat bahwa bentuk gelombang arus berfluktuatif hal ini disebabkan karena terdapat beban setrika yang akan otomatis "OFF" apabila mencapai titik panas maksimun. Pada pengujian arus menggunakan multimeter menunjukan nilai sebesar 6,76 A, sedangkan pada pengujian dengan menggunakan LabVIEW menunjukan nilai arus sebesar 6,34 A. Dari hasil tersebut dapat diketahui bahwa terdapat perbedaan nilai arus pada kedua pengujian dengan selisih (error) nilai arus sebesar 0,42 A.

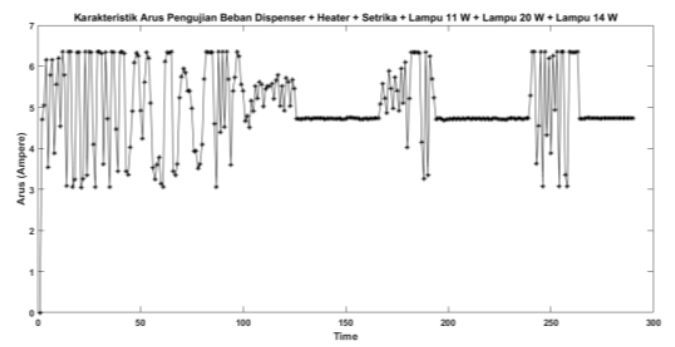

Gambar 12 Karakteristik Pengujian Beban Dispenser 350 W, Heater 1000 W Setrika 350 W, dan Lampu 45 W
DOI : $10.21070 /$ jeee-u.v\%vi\%i.1321

\subsection{Pengujian Fitur Pemantauan Beban Listrik Menggunakan Labview}

Tampilan pemantauan energi listrik pada LabVIEW terdiri dari beberapa menu, meliputi menu Home dan Monitoring. Selanjutnya akan dibahas fungsi dari masing-masing menu tersebut.

\subsection{Menu Home}

Tampilan menu Home dapat dilihat pada Gambar 4.30 dimana menu ini berisi beberapa perintah yang digunakan dalam mengatur sistem pemantauan energi listrik. Terdapat beberapa fungsi dalam menu ini diantaranya:

- Fungsi blok VISA resourse name digunakan sebagai saluran untuk komunikasi serial port, Pada komponen tersebut Visa Serial akan men-scan COM Serial mana yang sedang aktif dengan cara melihat inputan COM Arduino pada panel divice manager pada computer atau laptop.

- Fungsi baud rate (kecepatan komunikasi) mengindikasikan seberapa cepat data dikirim melalui komunikasi serial dengan satuan bps (bit per second) ini mengartikan bahwa berapa bit data dapat ditransfer setiap detiknya. "Untuk mengurangi error maka digunakan kecepatan standar yaitu 9.600 bps. Karena Semakin besar nilai baud rate, semakin tinggi kecepatan transfer. Namun demikian, karena komunikasi yang melibatkan sinyal elektrik dan proses sinkronisasi data sangat rentan dengan error dan derau, maka disarankan untuk tidak melebihi kecepatan 115.200 bps untuk komunikasi pada Arduino (Wardana, 2015)".

Kecepatan komunikasi (baud rate) dari sisi arduino maupun LabVIEW haruslah sama yaitu sebesar 9.600 bps (bit per second).

- Fungsi data bits merupakan kapasitas data (digit biner), jumlah informasi yang bisa dikirim oleh arduino ke LabVIEW.

- Fungsi Port digunakan sebagai sinyal pembacaan ADC dengan nilai 511, namun nilai ini akan berubah-ubah ketika diberi beban.

- Fungsi ACS Values digunakan untuk

- Fungsi Arus digunakan untuk pembacaan nilai arus. 

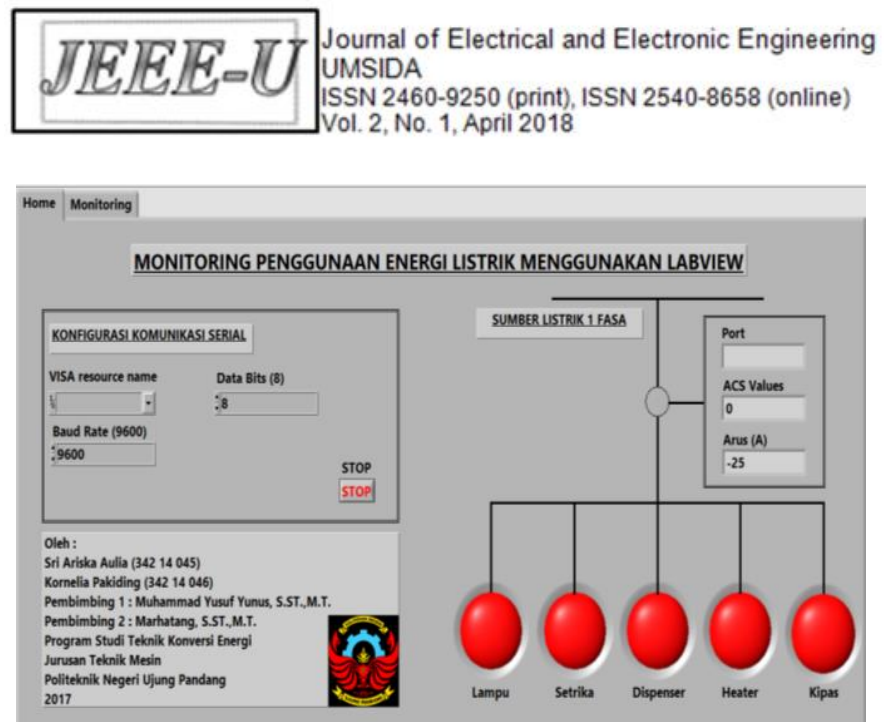

Gambar 13. Tampilan front panel Menu Home pada Fitur LabVIEW

\subsection{Menu Monitoring}

Menu ini berisi beberapa fitur yang berfungsi untuk memantau penggunaan energi listrik. Sistem pemantauan terdiri dari beberapa alat ukur yang ditampilkan dalam bentuk analog maupun digital. Alat ukur tersebut diantaranya, alat ukur arus, tegangan, daya, dan $\mathrm{kWh}$. Tampilan dari menu monitoring dapat dilihat pada gambar berikut.

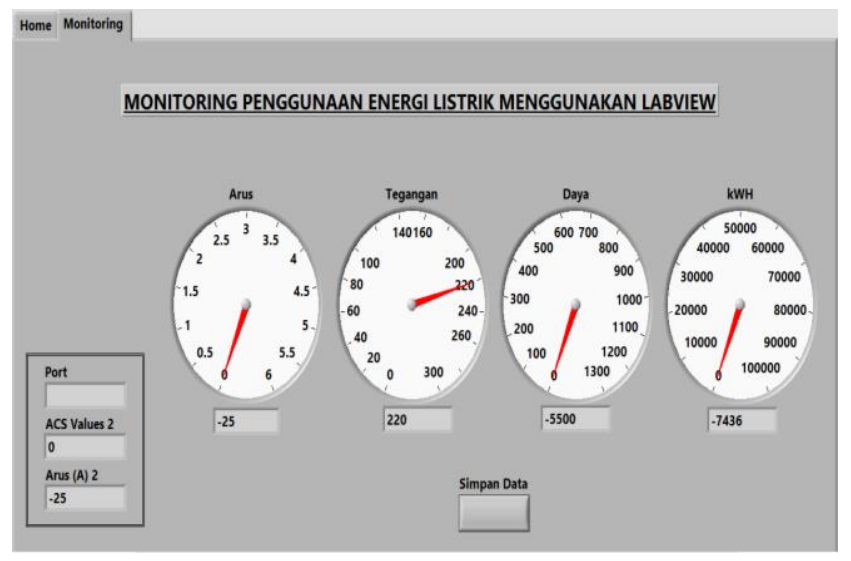

Gambar 14 Tampilan Menu Monitoring pada Fitur LabVIEW

Adapun tampilan Block diagram dari LabVIEW dapat dilihat pada Gambar 4.32. Block diagram adalah jendela tempat menuliskan perintah dan fungsi, berisikan source code berupa simbol-simbol, node dan garis sebagai dataflow untuk mengeksekusi program, termasuk kode dari front panel.
DOI : 10.21070/jeee-u.v\%vi\%i.1321

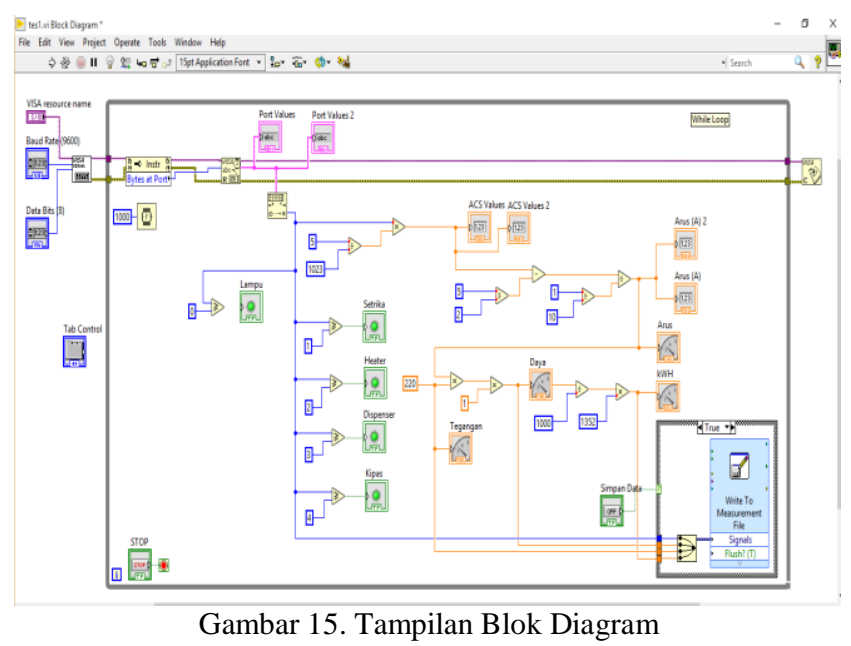

Untuk membaca input data serial melalui Port USB maka digunakan fungsi atau komponen Visa Serial. Dimana pada komponen tersebut Visa Serial akan men-scan COM Serial mana yang sedang aktif dengan cara melihat inputan COM Arduino pada panel divice manager pada computer atau laptop. Untuk konfigurasi komunikasi serial antara arduino dengan LabVIEW maka digunakan source code sebagai berikut:

- VISA Configure Serial Port

- VISA Flush I/O Buffer

- VISA Bytes at Serial Port

- VISA Read

- VISA Close

Jika pada saat proses connecting data dari Arduino dengan User Interfcae pada Lab View tidak terjadi error maka data selanjutnya akan dibaca dan diubah ke dalam bilangan decimal biasa dari bilangan decimal string agar data tersebut bisa dimasukan ke dalam buffer data. Pada proses buffer data akan diperoleh nilai arus, karena nilai data arus adalah nilai ADC 8 bit, maka untuk menghasilkan nilai arus dalam satuan ampere, disisipkan perhitungan :

Arus $=\left(\frac{\left(\text { port A } 0 \times\left(\frac{5}{1023}\right)\right)-2,5}{0,1}\right)$ kemudian hasil perhitungan arus akan ditampilkan dengan menggunakan icon decimal string to number. Nilai arus tersebut akan dikalikan dengan nilai tegangan konstan sebesar $220 \mathrm{~V}$ sehingga akan diperoleh nilai daya dan biaya pemakaian energi listrik akan diperoleh dengan mengalikan nilai daya dengan nilai tarif $1 \mathrm{kWh}$ pada golongan 1300 VA. Sedangkan, untuk menampilkan beban yang sedang aktif maka digunakan icon boolean. Case Structure digunakan untuk membuat program hanya akan membaca bila ada data di Serial Port. Hasil pembacaan data akan disimpan dalam format excel menggunakan icon write to measurement file. Untuk membuat program terus menerus membaca instruksi yang diterima maka digunakan icon While Loop. 


\subsection{Pengujian Beban Tunggal \\ 3.6.1 Beban Dispenser 350 Watt}

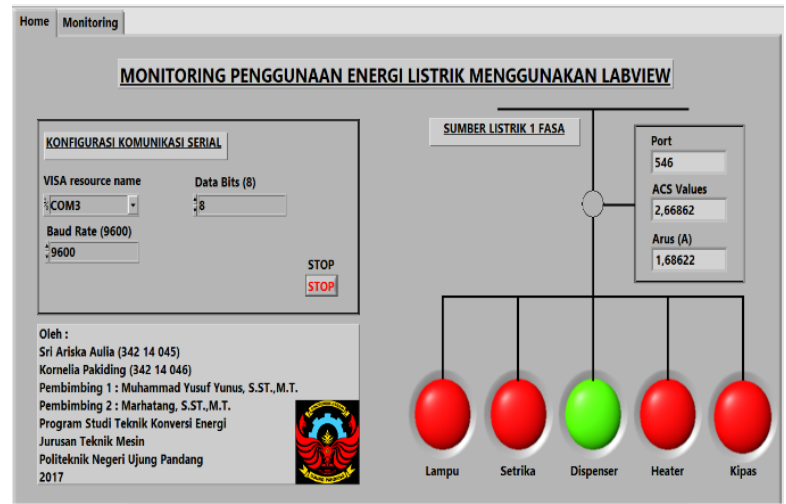

Gambar 16. Tampilan Menu Home pada Pengujian Beban Dispenser

Pada Gambar diatas terdapat 3 penununjukan yakni nilai port, ACS value, dan Arus. Untuk mengetahui arus yang mengalir pada sistem maka digunakan persamaan (15), maka diperoleh:

$$
\begin{aligned}
& \text { Arus }=\left(\frac{\left(\text { port A } 0 \times\left(\frac{5}{1023}\right)\right)-2,5}{0,1}\right) \\
& \text { Arus }=\left(\frac{\left(546 \times\left(\frac{5}{1023}\right)\right)-2,5}{0,1}\right)
\end{aligned}
$$

Arus $=1,68622$

Hasil perhitungan diatas sama dengan hasil pengukuran pada LabVIEW.

Berikut adalah tampilan menu monitoring pada pengujian beban dispenser.

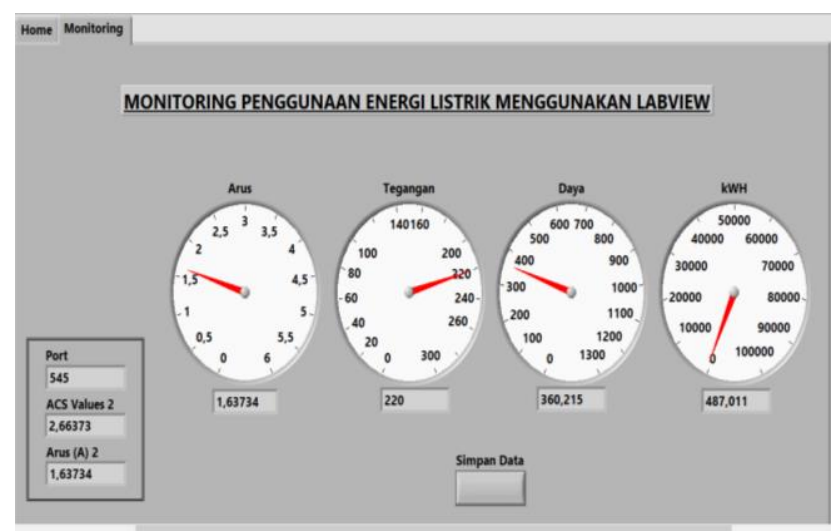

Gambar 17. Tampilan Menu Monitoring pada Pengujian Beban Dispenser

\subsubsection{Beban Setrika 350 Watt}

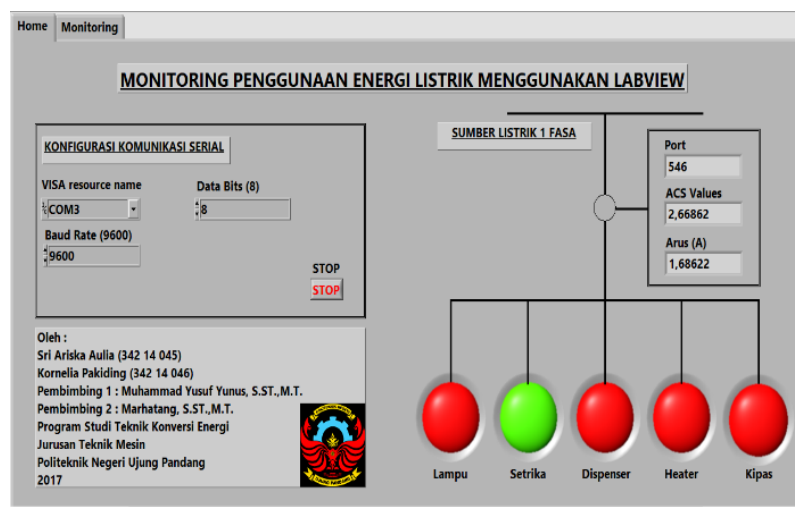

Gambar 18 Tampilan Menu Home pada Pengujian Beban Setrika

$$
\begin{aligned}
& \text { Arus }=\left(\frac{\left(\text { port A0 } \times\left(\frac{5}{1023}\right)\right)-2,5}{0,1}\right) \\
& \text { Arus }=\left(\frac{\left(546 \times\left(\frac{5}{1023}\right)\right)-2,5}{0,1}\right) \\
& \text { Arus }=1,68622
\end{aligned}
$$

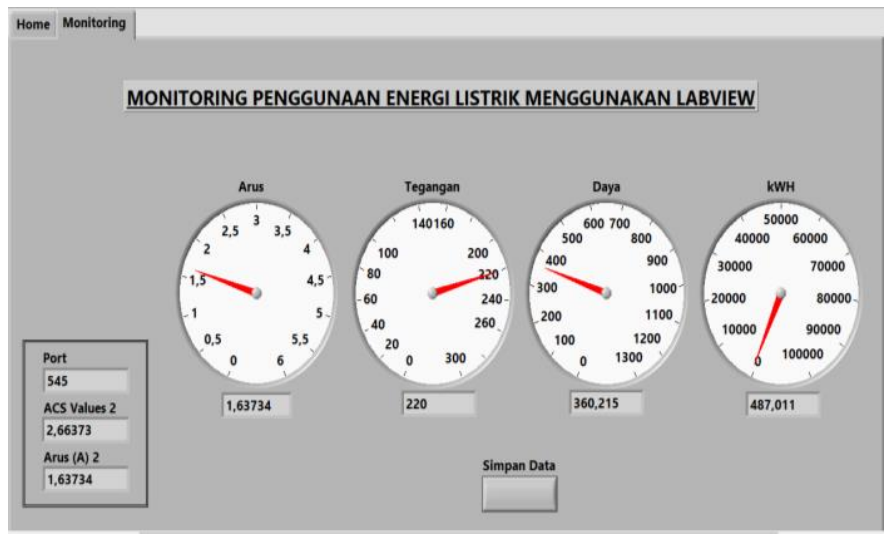

Gambar 19 Tampilan Menu Monitoring pada Pengujian Beban Setrika 


\subsubsection{Beban Lampu}

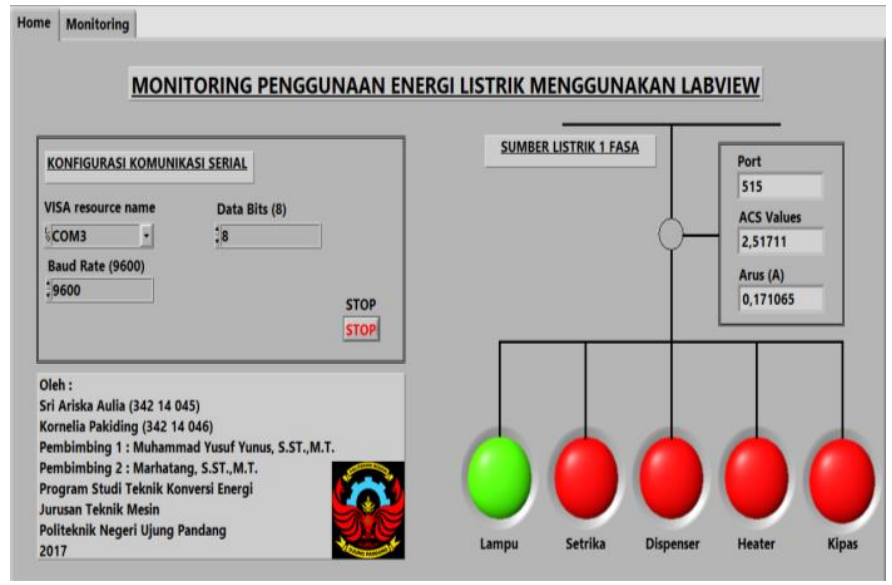

Gambar 20 Tampilan Menu Home pada Pengujian Beban Lampu

$$
\begin{aligned}
& \text { Arus }=\left(\frac{\left(\text { port } \mathrm{A} 0 \times\left(\frac{5}{1023}\right)\right)-2,5}{0,1}\right) \\
& \text { Arus }=\left(\frac{\left(515 \times\left(\frac{5}{1023}\right)\right)-2,5}{0,1}\right)
\end{aligned}
$$

Arus $=0,171065 \mathrm{~A}$

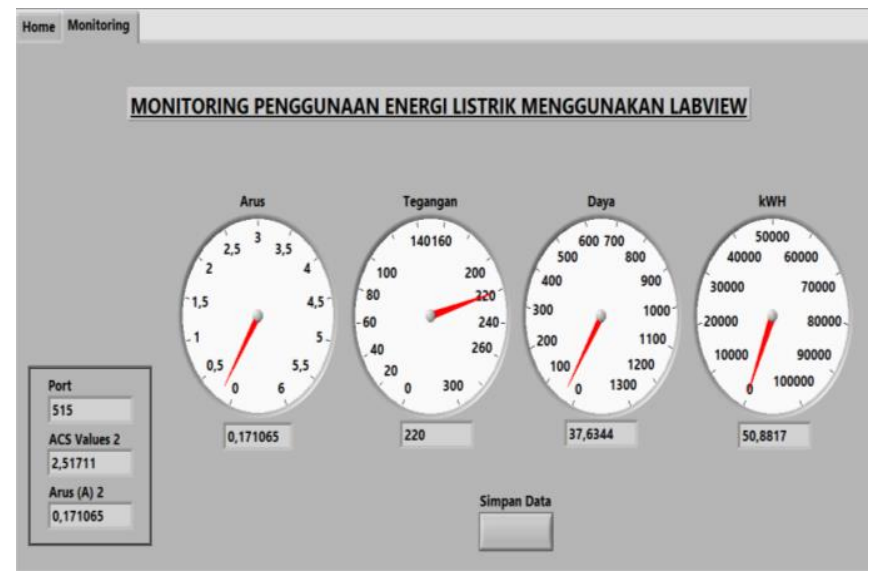

Gambar 21 Tampilan Menu Monitoring pada Pengujian Beban Lampu

\subsubsection{Beban Kipas Angin}

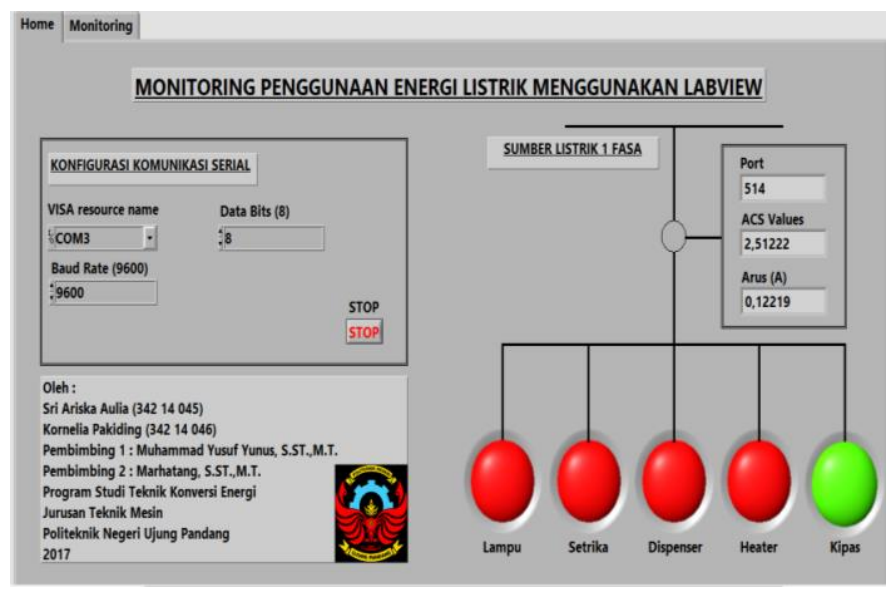

Gambar 22 Tampilan Menu Home pada Pengujian Beban Kipas Angin

$$
\begin{aligned}
& \text { Arus }=\left(\frac{\left(\text { port A } 0 \times\left(\frac{5}{1023}\right)\right)-2,5}{0,1}\right) \\
& \text { Arus }=\left(\frac{\left(514 \times\left(\frac{5}{1023}\right)\right)-2,5}{0,1}\right) \\
& \text { Arus }=0,12219 \mathrm{~A}
\end{aligned}
$$

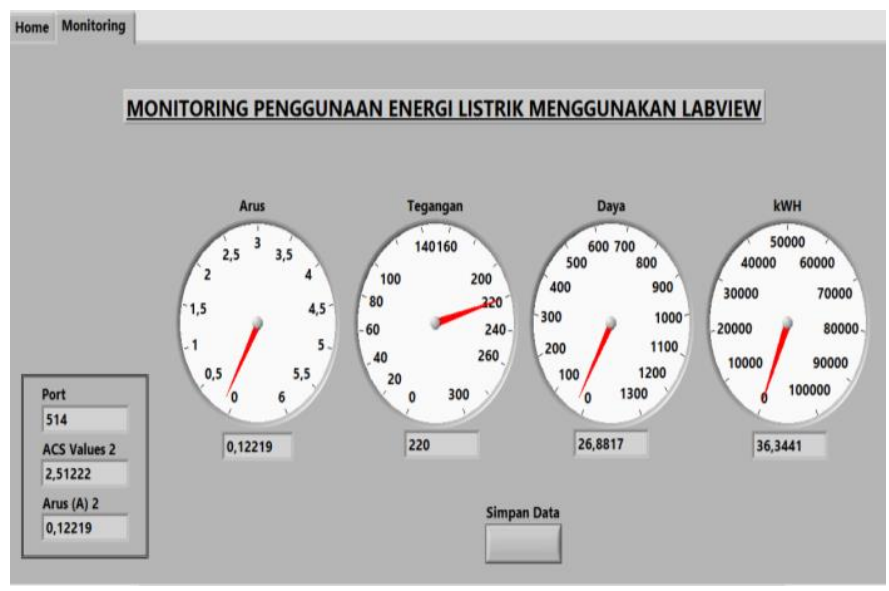

Gambar 23 Tampilan Menu Monitoring pada Pengujian Beban Kipas Angin 


\subsection{Pengujian Beban Kombinasi}

\subsubsection{Beban Setrika 350 W dan Lampu 45 W}

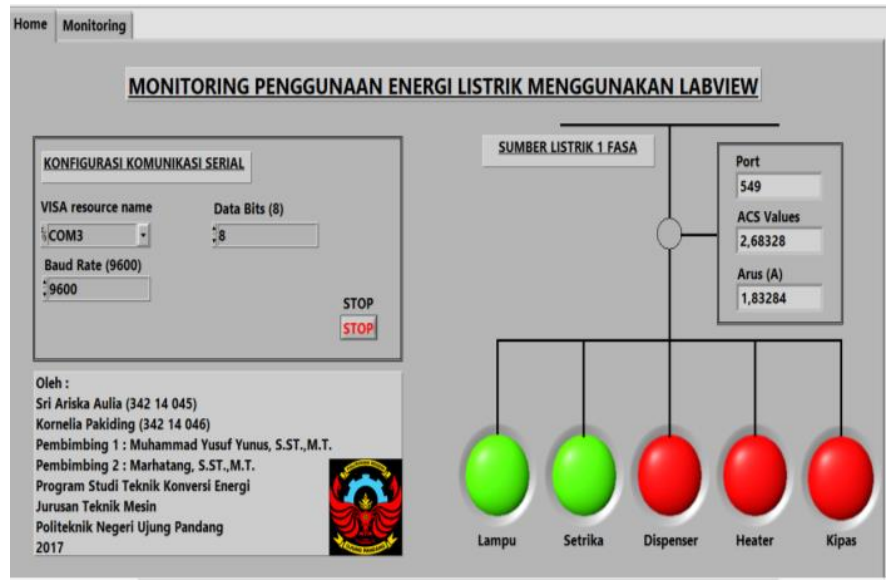

Gambar 24. Tampilan Menu Home pada Pengujian Beban Kombinasi Setrika dan Lampu

$$
\begin{aligned}
& \text { Arus }=\left(\frac{\left(\text { port A0 } \times\left(\frac{5}{1023}\right)\right)-2,5}{0,1}\right) \\
& \text { Arus }=\left(\frac{\left(549 \times\left(\frac{5}{1023}\right)\right)-2,5}{0,1}\right)
\end{aligned}
$$$$
\text { Arus }=1,83284 \mathrm{~A}
$$

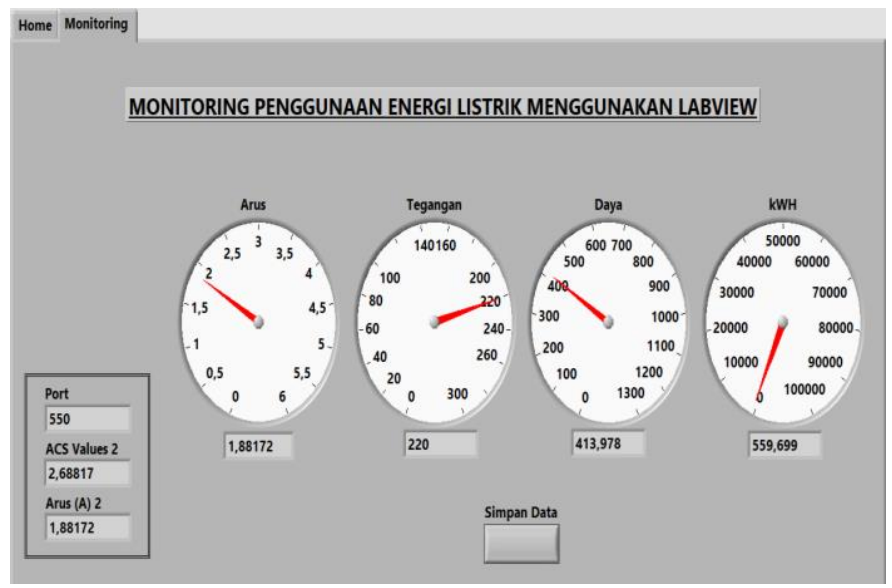

Gambar 25 Tampilan Menu Monitoring pada Pengujian Beban Kombinasi Setrika dan Lampu
3.7.2 Beban Dispenser 350 W, Setrika 350 W, dan Lampu $20 \mathrm{~W}$

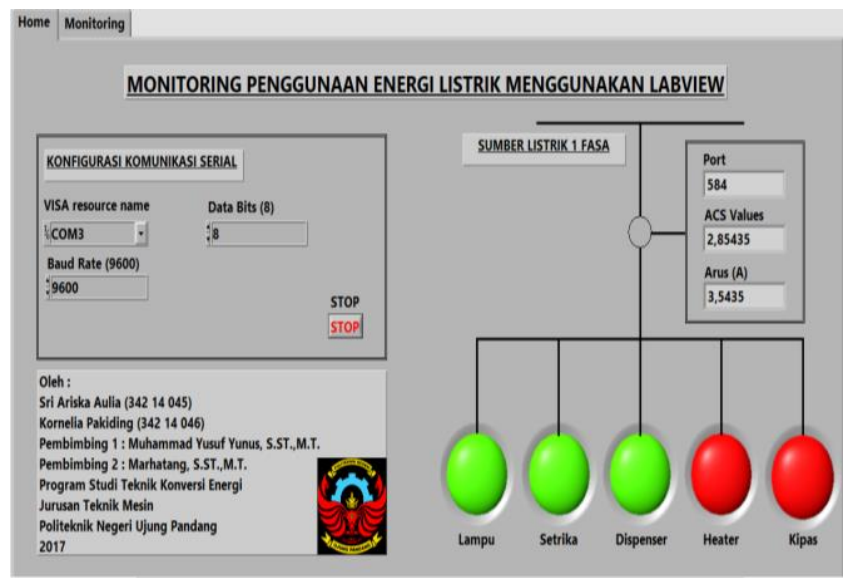

Gambar 26 Tampilan Menu Home pada Pengujian Beban Kombinasi Dispenser, Setrika dan Lampu

$$
\begin{aligned}
& \text { Arus }=\left(\frac{\left(\text { port A0 } \times\left(\frac{5}{1023}\right)\right)-2,5}{0,1}\right) \\
& \text { Arus }=\left(\frac{\left(584 \times\left(\frac{5}{1023}\right)\right)-2,5}{0,1}\right) \\
& \text { Arus }=3,5435 \mathrm{~A}
\end{aligned}
$$

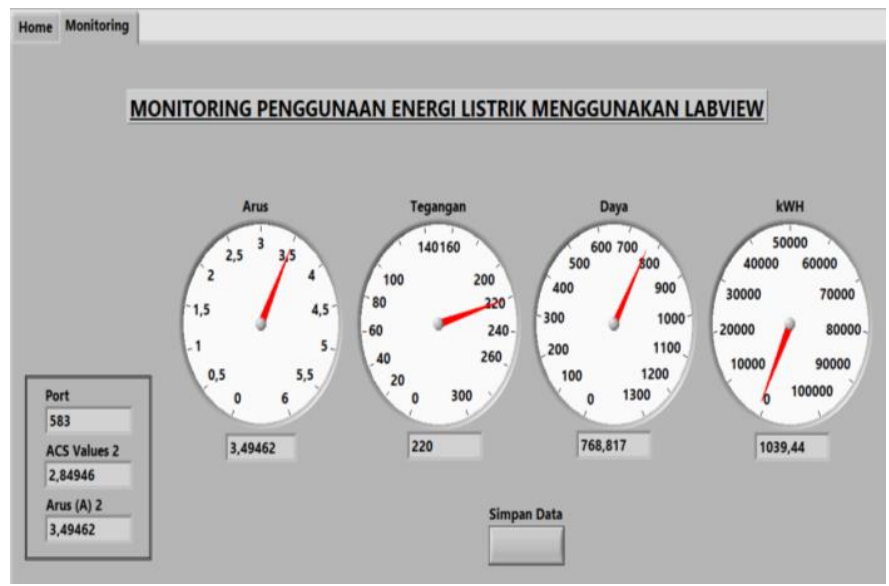

Gambar 27 Tampilan Menu Monitoring pada Pengujian Beban Kombinasi Dispenser, Setrika dan Lampu 
3.7.3 Beban Dispenser 350 W, Kipas Angin 35 W, Setrika $350 \mathrm{~W}$, dan Lampu $45 \mathrm{~W}$

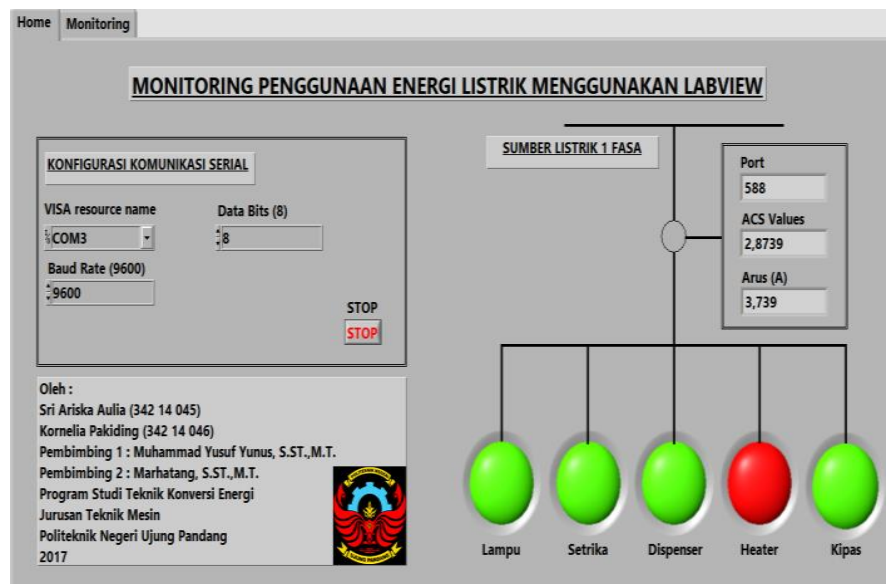

Gambar 28 Tampilan Menu Home pada Pengujian Beban Kombinasi Dispenser, Kipas Angin, Setrika dan Lampu

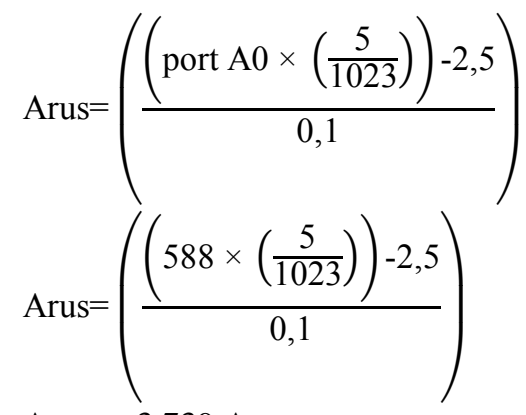

Arus $=3,739 \mathrm{~A}$

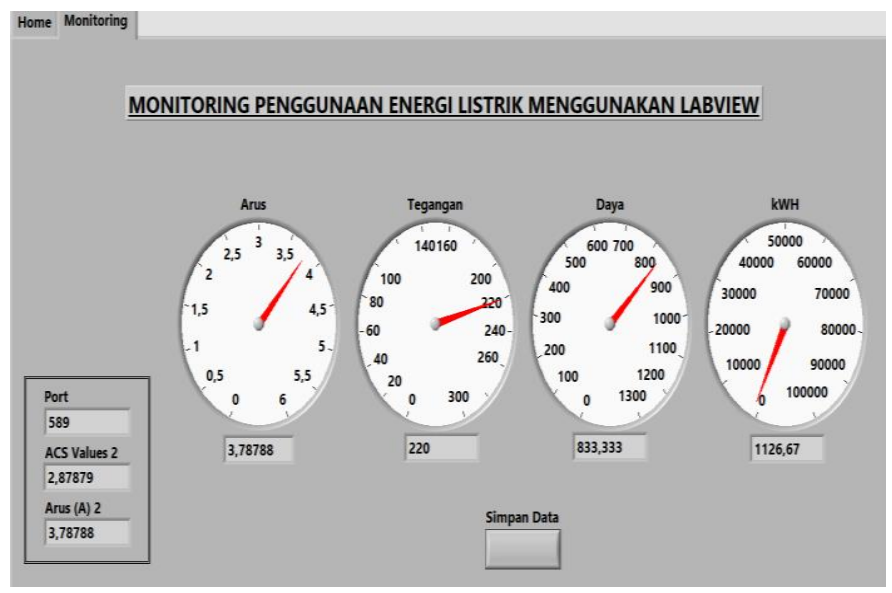

Gambar 29. Tampilan Menu Monitoring pada Pengujian Beban Beban Kombinasi Dispenser, Kipas Angin, Setrika dan Lampu

\section{KESIMPULAN}

1. Output dari penelitian ini adalah rancang bangun monitoring pemkaian energy listrik menggunakan LabVIEW.

2. Pengujian dilakukan dengan metode pengukuran langsung sebagai pembanding

3. Dari hasil penerapan, monitoring dapat dengan baik dilakukan, yang ditunjukkan dengan selisih error hasil pengukuran dengan pengukuran dari LabView.

\section{Daftar Pustaka}

[1] H. Koko, "Desain Smart Meter Untuk Memantau Dan Identifikasi Pemakaian Energi Listrik Pada Sektor Rumah Tangga Menggunakan Backpropagation Neural Network," ITS Surabaya, 2015.

S. Suryaningsih, "RANCANG BANGUN ALAT PEMANTAU PENGGUNAAN ENERGI LISTRIK RUMAH TANGGA BERBASIS INTERNET," presented at the SEMINAR NASIONAL FISIKA 2016 UNJ, 2016.

I. D. Utomo, "PROSES PENGAMBILAN DATA ENERGI (KWH) METER ELEKTRONIK PADA GARDUINDUK 150 KV PT. PLN (PERSERO) P3BJB REGION JAWA TENGAH DAN DIY UNITPELAYANAN TRANSMISI SEMARANG," presented at the Makalah Seminar Kerja Praktek, 2012.

[4] I. Ismujianto and I. Isdawimah, "DESAIN AKUISISI DATA KUALITAS DAYA LISTRIK," PoliTeknologi, vol. 15, 2017.

[5] J. Roos, I. Lane, E. Botha, and G. P. Hancke, "Using neural networks for non-intrusive monitoring of industrial electrical loads," in Instrumentation and Measurement Technology Conference, 1994. IMTC/94. Conference Proceedings. 10th Anniversary. Advanced Technologies in I \& M., 1994 IEEE, 1994, pp. 1115-1118.

[6] Y.-Y. Hong and J.-H. Chou, "Nonintrusive energy monitoring for microgrids using hybrid selforganizing feature-mapping networks," Energies, vol. 5, pp. 2578-2593, 2012. 